\title{
Cutlink Cleaning Head with a Spreading Feature for Biological Sprout Control
}

\author{
Leena Hamberg, Markus Strandström, Timo Saksa
}

\begin{abstract}
The ability of deciduous trees to sprout efficiently after cutting is problematic in young forests where the target is to cultivate coniferous trees for industry. Since the use of chemicals has been restricted, new alternatives are needed. One potential and environmentally friendly option is biological sprout control that is based on the use of a white-rot fungus, Chondrostereum purpureum (Pers. Ex Fr.) Pouzar. This method has been efficient in earlier investigations when performed manually, but efficient, fully mechanized devices which are able to cut and treat stumps with a fungus are still unavailable. Therefore, the efficacy of biological sprout control conducted with a Cutlink cleaning head equipped with a spreading feature was studied in two young Norway spruce (Picea abies (L.) H. Karst.) forests in central Finland.

Sample plots for the control (cutting deciduous saplings only) and fungal treatment (cutting and spreading fungal inoculum on fresh stump surfaces) were established, and the ability of the Cutlink cleaning head in preventing sprouting of silver and downy birch (Betula pendula Roth and B. pubescens Ehrh., respectively) in the sample plots was investigated for two years. In the near vicinity of cultivated Norway spruce, the proportion of cut deciduous saplings varied from 50-60\% after the Cutlink operation. The average mortality of silver and downy birch stumps in the fungal treatment plots was ca. $40 \%$, while stump mortality in the control, i.e., cutting only, was only ca. $13 \%$, after two years. Stump mortality increased up to $73 \%$ if the stumps did not include old branches, i.e., the stump was cut to a low enough height.

These results confirmed that the Cutlink cleaning head is a potential tool in young stand management operation but further development will be needed in working methods in order to achieve lower stump heights (no branches on the stump) and also to increase the proportion of cut saplings.
\end{abstract}

Keywords: Chondrostereum purpureum, stump mortality, silver and downy birch, efficacy, mechanical sprout control

\section{Introduction}

In young forests, where conifers are planted to produce timber, naturally grown deciduous trees compete for resources available for tree growth (Huuskonen et al. 2020, Wagner et al. 2006). In order to provide more growing space and better conditions for conifers, deciduous saplings are usually cut with a clearing saw. Yet, the fast sprouting of deciduous trees from stumps makes cutting an inefficient option, and therefore the treatment should often be repeated (Jobidon 1998, Becker et al. 2005, Thiffault and Roy 2011, Äijälä et al. 2019). Chemicals are efficient in sprout control, but their use is not recommended or allowed due to harm- ful impacts on the environment (Jobidon 1998, Pitt et al. 1999, Willoughby et al. 2009, Thiffault and Roy 2011, PEFC 2017).

A silver-leaf fungus, Chondrostereum purpureum (Pers. Ex Fr.) Pouzar, is common in wounded deciduous trees in boreal and temperate forests but it is very rarely found in conifers as a saprophyte, i.e., in dead wood (Etheridge and Morin 1963, Ramsfield et al. 1996, Gosselin et al. 1995, Vartiamäki et al. 2008b). This fungal species is especially efficient in decaying wood e.g., in birch (Betula papyrifera Marshall, B. pendula Roth and B. pubescens Ehrh.), aspen (Populus tremula L., Populus tremuloides Michx.) and alder species (Alnus incana (L.) 
Moench, Alnus viridis ssp. sinuata (Regel) A. Löve et D. Löve) and therefore it could be utilized as an environmentally friendly option in sprout control (Jobidon 1998, Harper et al. 1999, Lygis et al. 2012, Hamberg et al. 2014, 2015, Hamberg and Hantula 2016, 2018). In biological sprout control, the fungus is spread on stump surfaces immediately after cutting, and from there the fungus can grow within a stump, decay it and finally kill a tree host (Hamberg et al. 2017).

Several investigations have been performed to investigate the efficacy of $C$. purpureum as biological sprout control agent (Spiers and Hopcroft 1988, de Jong 2000, Dumas et al. 1997, Becker et al. 2005, Vartiamäki et al. 2008a, Roy et al. 2010, Lygis et al. 2012, Bellgard et al. 2014), but in most of them, spreading of fungal inoculum has been applied manually, although in practice it is almost impossible to treat all saplings without motor manual or mechanized spreading devices. Some investigations have been performed with clearing saws able to spread fungal inoculum on freshly cut stump surfaces (Roy et al. 2010, Laine et al. 2020b), and with fully mechanized devices (Laine et al. 2019, 2020a). Especially, fully mechanized devices with a spreading feature would need to be attached to a harvester that can carry the weight of inoculum medium, cut saplings, and apply fungal inoculum immediately on freshly cut stump surfaces, a feature that is important in efficient sprout control (Hamberg and Hantula 2020). However, the sprout control efficacy of fully mechanized devices has been rather low so far (Laine et al. 2019, 2020a), and therefore new alternatives are needed.

In this study, the aim was to investigate the biological sprout control efficacy of a fully mechanized device, a Cutlink cleaning head (Kesmac Ltd.). We hypothesize that the efficacy of Cutlink would exceed that achieved in earlier investigations with other fully mechanized devices (ca. 34-42\% mortality, Laine et al. 2019, 2020a).

\section{Materials and Methods}

\subsection{Field Experiments}

Two field sites included in the study are located in Orivesi and Ruovesi, southern Finland (Table 1). Sites were clear-felled nine and seven years before the treatments in the field, respectively, and Norway spruce (Picea abies (L.) H. Karst.) seedlings were planted at the sites one and two years later, respectively. Thus, at the Orivesi site, the stand was eight years-old, whereas at the Ruovesi site, the stand was four years-old, and therefore, spruces were taller at the Orivesi than at the Ruovesi site. Both sites included plenty of naturally grown deciduous saplings, mainly silver and downy birches (Betula pendula and B. pubescens). The number of birch saplings was approximately at the same level at both sites, with about 20,000 saplings per hectare. At both sites, six sample plots, three for the control (cutting only) and three for the fungal treatment (cutting and applying Chondrostereum purpureum inoculum on freshly cut stumps) were established (Fig. 1). Each sample plot was $15 \times 25 \mathrm{~m}^{2}$ in size and included five sub-sample plots, each consisting of five birch stumps to be investigated.

The experiment was established on the $5^{\text {th }}$ and $6^{\text {th }}$ of July 2018 at the Ruovesi and Orivesi sites, respectively. First, in control sample plots, deciduous saplings were cut only, and after that, in fungal treatment sample plots, deciduous saplings were cut and an inoculum

Table 1 Description of study sites located in southern Finland, and the number and height of Norway spruce (Picea abies) and silver and downy birch (Betula pendula and B. pubescens) saplings at the sites. Means with standard deviations have been provided for the number and height of saplings

\begin{tabular}{|c|c|c|c|c|c|c|c|}
\hline Site & $\begin{array}{c}\text { Geographic } \\
\text { coordinates }\end{array}$ & Soil & $\begin{array}{c}\text { Site } \\
\text { type }{ }^{\text {a }}\end{array}$ & $\begin{array}{c}\text { Stand } \\
\text { age }\end{array}$ & $\begin{array}{c}\text { Number of planted } \\
\text { spruces per } \\
\text { hectare }\end{array}$ & $\begin{array}{c}\text { Spruce } \\
\text { height } \mathrm{cm}^{\text {b }}\end{array}$ & $\begin{array}{c}\text { Number of naturally grown } \\
\text { birch saplings per hectare }^{c}\end{array}$ \\
\hline Orivesi & $\begin{array}{c}61^{\circ} 40^{\prime} 9,331^{\prime \prime} \mathrm{N} \\
24^{\circ} 29^{\prime} 56,888^{\prime \prime} \mathrm{E}\end{array}$ & $\begin{array}{c}\text { Coarse } \\
\text { moraine }\end{array}$ & OMT & 8 & $1933 \pm 406$ & $187 \pm 29$ & $17,889 \pm 8345$ \\
$\mathrm{~cm}^{\mathrm{c}}$
\end{tabular}

${ }^{a}$ Finnish site type classification based on understory vegetation composition by Cajander (1926): OMT is Oxalis-Myrtillus type and MT is Myrtillus type forest. OMT is slightly better in soil fertility than MT

${ }^{\mathrm{b}}$ Investigated within $50 \mathrm{~m}^{2}$ sub sample plots (radius $3.99 \mathrm{~m}$ )

${ }^{c}$ Investigated within $20 \mathrm{~m}^{2}$ sub sample plots (radius $2.52 \mathrm{~m}$ ). Saplings at least $10 \mathrm{~cm}$ in height were included in investigations. The number of deciduous saplings other than birches was $6750 \pm 9258$ and $6500 \pm 2990$ saplings per hectare at the Orivesi and Ruovesi sites, respectively 

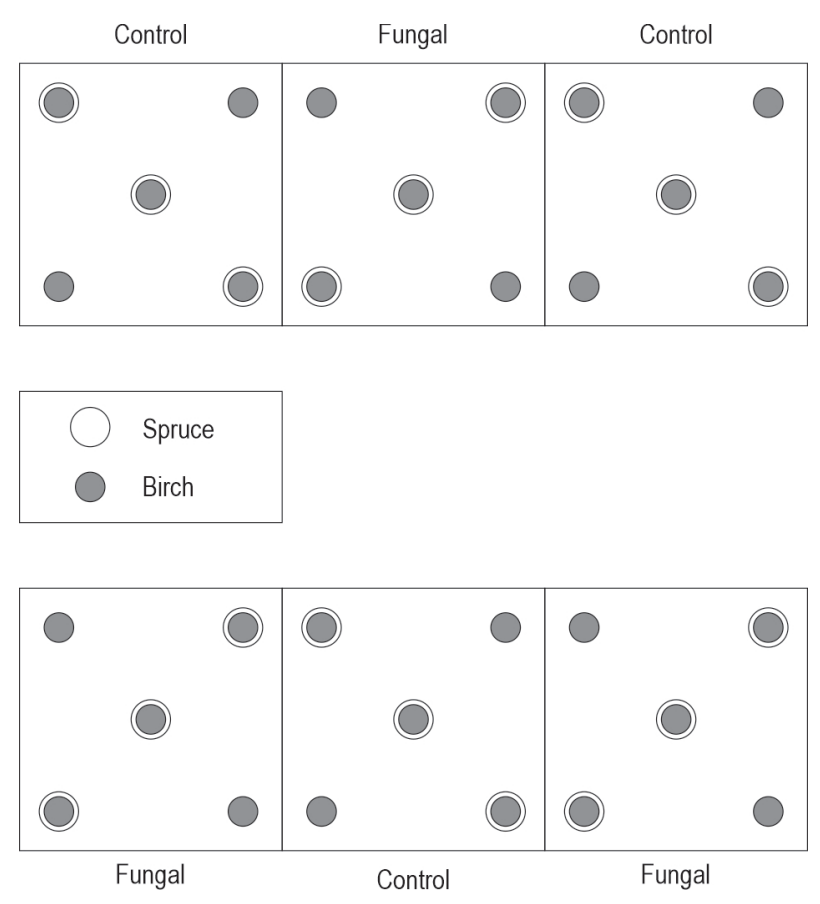

Fig. 1 Schematic layout of sample plots and sub-sample plots

medium was spread on freshly cut stump surfaces. Inoculum medium provided by Verdera Ltd. included Chondrostereum purpureum strain R5 (Hamberg et al. 2015), and it included $4 \times 10^{5}$ colony forming units per gram (CFU g ${ }^{-1}$ ) (Gonzáles 1996). It was diluted with tap water 1:100 before treatments in the field.

Both treatments were performed with the Cutlink cleaning head (Kesmac Ltd.). Cutlink is a device constructed for clearing all types of small-diameter wood (Routa et al. 2019). It can be used in mechanized sprout control in young forest management, next to roads and railways, below electric power lines and above gas pipelines. Rotating spire screws force the stems of saplings against the stationary blade, and inoculum medium is spread immediately onto stump surfaces from the underside of the blade (Fig. 2). In this study, a three screw cleaning head was attached to the boom of a harvester (Valmet 901.3). The harvester was also equipped with a tank for inoculum medium.

Within sub-sample plots, altogether 300 silver and downy birch saplings at least $0.5 \mathrm{~cm}$ in basal diameter (Fig. 1) were marked soon after the treatments with a name tag. 150 saplings were marked within the control and 150 within the fungal sample plots. Birch species were not investigated separately, since no difference has been found in their responses to C. purpureum infection (Hamberg et al. 2015). Furthermore, three center points were established within each sample plot

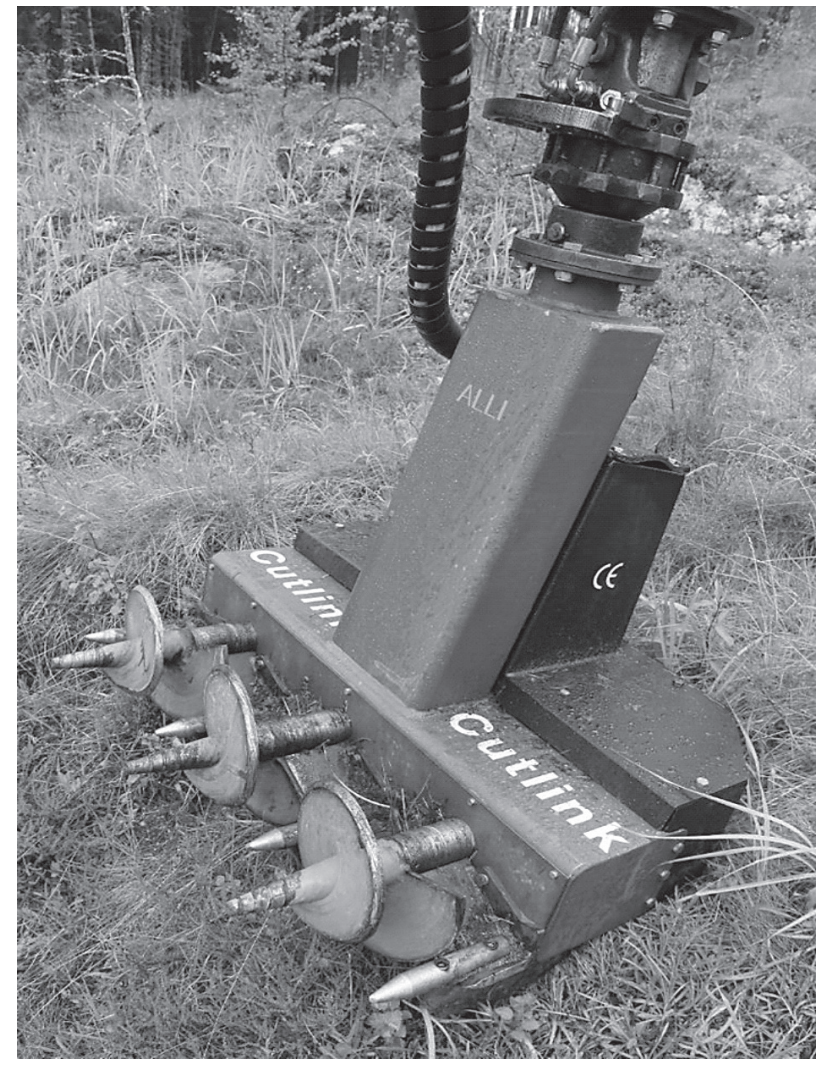

Fig. 2 Cutlink cleaning head with a spreading feature for fungal inoculum. Picture: Markus Strandström

from one corner to another, to measure the success of Cutlink in cutting deciduous saplings around Norway spruces (Picea abies) planted at the site (Fig. 1). Thus, the proportion of cut deciduous saplings was investigated in the near vicinity of spruces (within $0.5 \mathrm{~m}$ radius) within a $3.99 \mathrm{~m}$ radius around the three center points. At the Orivesi site, all surroundings of spruces more than $1 \mathrm{~m}$ in height, and at the Ruovesi site, all planted spruces at least $0.5 \mathrm{~m}$ in height were investigated. Altogether, 228 spruce surroundings, 119 within the control and 109 within the fungal sample plots were included in the study.

The sites were visited during August-September 2018, 2019 and 2020, i.e., 2.5 months, one and two years after the start of the experiment. The diameters (at height of $20 \mathrm{~cm}$ from the soil surface) and heights of stumps $(\mathrm{cm})$ were measured. To evaluate the ability of Cutlink performance in sprout control, we recorded whether the sapling was cut and detached or whether the top of a sapling was totally or partly attached to a stump. Furthermore, the occurrence of older branches on the stump (grown before the experiment was established in the field) was recorded. The number of new 
living stump sprouts (grown after the treatments) was counted and the height of the tallest new sprout measured from soil surface to the top of the sapling $(\mathrm{cm})$. Also, the height of the tallest old branch $(\mathrm{cm})$ was measured if it was higher than the tallest new living stump sprout grown after the treatment. Browsing of animals on sprouts and the occurrence of C. purpureum fruiting bodies on each stump was recorded, and the number of other saplings or stumps around each investigated stump was counted within a radius of $0.5 \mathrm{~m}$.

\subsection{Statistical Analyses}

All statistical analyses were performed with the statistical program R (R Core Team 2019). First, the effect of stump height on the probability of occurrence of old branches on a stump was estimated with a generalized linear model (GLM). In this model, the occurrence of old branches ( $\mathrm{a}$ factor with two levels: $0=$ no old branches on a stump, 1 = old branches occur on a stump) was as a response and stump height $(\mathrm{cm})$ and site (a factor with two levels: Orivesi and Ruovesi sites) were explanatory variables. The model was estimated assuming binomial distribution with logit link function.

Second, the effects of the treatments and other covariates (see below) on stump mortality, and the number and maximum height of stump sprouts (or old branches) were investigated using mixed models. Generalized linear mixed models (GLMMs) were used to estimate the effects on stump mortality and the number of stump sprouts. These models were estimated using library lme4 and function glmer (Bates et al. 2015). In the mortality model, stump mortality (a factor with two levels: 0 = stump is living, 1 = stump is dead, i.e., no stump sprouts) was as a response variable, and the model was estimated assuming binomial distribution with logit link. Stump sprout model included the number of new stump sprouts grown after the treatment as a response (integer), and the model was estimated assuming Poisson distribution with log link. Linear mixed model (LMM) was used to estimate effects on the height of stump sprouts. In the sprout height model, the maximum height of stump sprouts (or old branches if they were taller, $\mathrm{cm}$ ) was as a response variable, and the model was estimated using library nlme and function lme, assuming normal distribution (Pinheiro et al. 2019). However, the height was log transformed and one outlier was removed from the final model based on a residual plot (fitted values vs. residuals). All observations were included in the mortality model, whereas only living stumps having at least one stump sprout (or older branches) were included in the sprout number and height models.
In the mortality and stump sprout models (number and height), explanatory variables were 1) treatment (a factor with two levels: control vs. fungal treatment), 2) year (a factor with three levels: 2018, 2019 and 2020), 3) stump diameter $(\mathrm{mm}), 4)$ the number of other saplings or stumps around an investigated sapling within a $0.5 \mathrm{~m}$ radius, 5 ) the occurrence of old branches (a factor with two levels: $0=$ no old branches on a stump, $1=$ old branches on a stump), and 6) site (a factor with two levels: Orivesi site vs. Ruovesi site). An interaction term between treatment and year was included in the models, but as it was not statistically significant, it was removed from the final models. As random factors we had three nested variables, i.e., site, sample plot and sub-sample plot, to account for the fact that stumps within a site, within a sample plot and within a subsample plot may be more similar than randomly measured stumps. Site was included in the models as both a fixed and random factor since sites included in the study were rather different in age (see Table 1). However, in the maximum height of stump sprout (or old branches) model, site was included as a fixed factor only in order to be able to get $p$-value for differences between the sites. Browsing was not accounted for in the maximum height model since browsing was not observed frequently in investigated stump sprouts. Result figures were drawn in $\mathrm{R}$ based on the predicted values of the models when stump diameter and the number of other saplings and stumps around an investigated stump were kept in their means. Library AIC cmodavg was used to calculate the estimated values for the maximum height of stump sprouts (Mazerolle 2019).

\section{Results}

\subsection{Ability of Cutlink to Cut Saplings Around Norway Spruces}

Around cultivated Norway spruces, $49 \%$ of the deciduous saplings (mainly silver and downy birch) in the control, and $40 \%$ of the deciduous saplings in the fungal treatment were not cut. The amount of C. purpureum inoculum used at the study sites was 580 litre per hectare, 533 litre at the Orivesi site and 622 litre at the Ruovesi site per hectare.

\subsection{Investigated Birch Stumps}

Investigated birch stumps were rather similar in stump diameter at both sites (in Orivesi site, $1.7 \pm 0.9 \mathrm{~cm}$ in mean diameter \pm standard deviation in the fungal treatment and $1.4 \pm 0.6 \mathrm{~cm}$ in the control, and at the Ruovesi site, $1.4 \pm 0.5 \mathrm{~cm}$ in the fungal treatment and $1.3 \pm 0.6 \mathrm{~cm}$ in the control). After the treatments by the Cutlink, $19 \%$ of the control stumps were not cut 
properly since the top of a sapling was still attached to stumps, whereas in the fungal treatment, $23 \%$ of stumps had the top of a sapling attached to a stump. $57 \%$ of the control (59\% at the Orivesi site and 55\% at the Ruovesi site) and $62 \%$ of the stumps treated with fungal inoculum had old branches ( $76 \%$ at the Orivesi site and $48 \%$ at the Ruovesi site), that grew before the treatments in the field. An increase in stump height was associated with an increase in the probability of occurrence of old branches in a stump $(p<0.001, \mathrm{GLM})$. The stumps that included old branches were higher than those that did not have them (Table 2). Stumps were higher at the Orivesi than at the Ruovesi site $(p=0.022)$.

Two years after the fungal treatment, in 2020, stump mortality of birches was $40 \%$, whereas in the control it was $13 \%$. However, closer investigation revealed that there were several factors affecting stump mortality. Although mortality was clearly higher in the fungal treatment than in the control ( $p<0.001$, GLMM), site and the occurrence of old branches in stumps also determined mortality figures (Table 3, Fig. 3). At the younger site (Ruovesi), stump mortality was clearly higher than that at the older site $(p=0.035)$. Mortality was higher if stumps did not include old branches $(p<0.001)$. In the fungal treatment, final mortality two years after the treatments in stumps including old branches was 10 and $28 \%$ at the older and younger site (Orivesi and Ruovesi, respectively), whereas for stumps without old branches it was 44 and $73 \%$, respectively.

The number of stump sprouts (grown after the treatments) was slightly lower in the fungal treatment than in the control ( $p=0.022, \mathrm{GLMM})$, and lower for stumps having old branches (grown before the treatments, $p<0.001$, Table 3, Fig. 4). However, no differences were found between the sites $(p=0.406)$.

The maximum height of stump sprouts (or old branches in case they were higher than new sprouts) did not differ between the fungal treatment and the control ( $p=0.488$, LMM, Table 3, Fig. 5). However, two years after the treatments, sprouts (or old branches) were ca. $30 \mathrm{~cm}$ higher on stumps having old branches than on stumps without them $(p<0.001)$. At the younger site (Ruovesi), sprouts were shorter than those at the older site $(p=0.003)$.

The occurrence of fruiting bodies on stumps treated with C. purpureum was highest after the second growing season, especially for stumps without old branches (Table 4). In the control, fruiting bodies were occasionally observed only after the second growing season at the younger site (Ruovesi) on stumps that did not have old branches.
Table 2 The height of birch (Betula pendula and B. pubescens) stumps (cm) after cutting in the control (cutting only) and the fungal treatment (cutting and applying Chondrostereum purpureum hypha on stump surfaces) at two sites investigated. The work was performed using the Cutlink cleaning head. Stump height for stumps including old branches grown before the treatments and those without old branches have been presented

\begin{tabular}{|l|c|c|c|c|}
\hline \multirow{2}{*}{ Site } & \multirow{2}{*}{ Treatment } & \multirow{2}{*}{$n$} & \multicolumn{2}{|c|}{ Stump height, cm } \\
\cline { 4 - 5 } & & & Old branches & No old branches \\
\hline \multirow{2}{*}{ Orivesi } & C. purpureum & 75 & 60 & 43 \\
\cline { 4 - 5 } & Control & $74^{\mathrm{a}}$ & 60 & 55 \\
\hline \multirow{2}{*}{ Ruovesi } & C. purpureum & 75 & 49 & 43 \\
\cline { 4 - 6 } & Control & 75 & 52 & 41 \\
\hline
\end{tabular}

${ }^{a}$ One sapling out of 75 was not cut at all, and therefore it was removed from the data

An increase in stump mortality, the number and height of stump sprouts, were positively associated with an increase in stump diameter (GLMMs and LMM, Table 3). Furthermore, an increase in stump mortality, and decrease in the number and height of stump sprouts was associated with an increase in the number of other saplings and stumps around an investigated stump (Table 3 ).

\section{Discussion}

The Cutlink cleaning head was promising in biological sprout control, although the results revealed that its performance should be further developed. The sprout control efficacy was clearly higher in the fungal treatment than in the control, which is the minimum requirement for a successful sprout control device capable of both cutting saplings and spreading fungal inoculum. In the fungal treatment plots, ca. $40 \%$ of investigated silver and downy birches were dead two years after the treatment, corresponding to mortality percentages observed with other sprout control devices capable of spreading fungal inoculum (Laine et al. 2019, 2020a). Thus, based on this study, the hypothesis of better sprout control efficacy of the Cutlink could not be verified. However, closer investigation revealed that even $73 \%$ stump mortality can be achieved with the Cutlink when saplings have been cut so that stumps do not include old branches. Effects of the fungal treatment on the number of stump sprouts in living stumps were slight but still significantly different from the control: there were fewer sprouts in the fungal treatment as also observed in an earlier biocontrol device study (Laine et al. 2020a). 
Table 3 The effect of Chondrostereum purpureum treatment on mortality of birch (Betula pendula and B. pubescens) stumps, and the number and maximum height of stump sprouts (generalized linear mixed models, GLMMs and a linear mixed model, LMM, respectively). The treatments were performed using the Cutlink cleaning head with a spreading feature (spreading was not used in the control). Coefficients with standard errors (Coeff. \pm SE) have been presented. The sign of the coefficient indicates the direction of the effect (e.g., minus means negative effect). Statistically significant results have been indicated as follows: ${ }^{*} 0.010 \leq p<0.050 ;{ }^{* *} 0.001 \leq p<0.010$; ${ }^{* * *} p<0.001$. Living stumps only have been included in the models concerning stump sprouts (number and maximum height). One outlier was removed from the maximum height model. See Figs. 3-5

\begin{tabular}{|l|c|c|c|c|c|c|c|c|c|}
\hline Model $^{\mathrm{a}}$ & $n$ & $\begin{array}{c}\text { Intercept } \\
\text { Coeff. } \pm \text { SE }\end{array}$ & $\begin{array}{c}\text { Treatment }^{\mathrm{b}} \\
\text { Coeff. } \pm \text { SE }\end{array}$ & $\begin{array}{c}\text { Year 2019 } \\
\text { Coeff. } \pm \text { SE }\end{array}$ & $\begin{array}{c}\text { Year 2020 } \\
\text { Coeff. } \pm \text { SE }\end{array}$ & $\begin{array}{c}\text { Stump diameter }^{d} \\
\text { Coeff. } \pm \text { SE }\end{array}$ & $\begin{array}{c}\text { Other saplings } \\
\text { around }^{\mathrm{e}} \\
\text { Coeff. } \pm \text { SE }\end{array}$ & $\begin{array}{c}\text { Old branches }^{\dagger} \\
\text { Coeff. } \pm \text { SE }\end{array}$ & $\begin{array}{c}\text { Site }^{9} \\
\text { Coeff. } \pm \text { SE }\end{array}$ \\
\hline Mortality & 897 & $-10.629 \pm 1.213^{* * *}$ & $2.684 \pm 0.584^{* * *}$ & $3.613 \pm 0.561^{* * *}$ & $4.510 \pm 0.577^{* * *}$ & $0.174 \pm 0.027^{* * *}$ & $0.080 \pm 0.033^{*}$ & $-1.922 \pm 0.330^{* * *}$ & $1.211 \pm 0.573^{*}$ \\
\hline $\begin{array}{l}\text { Sprout } \\
\text { number }\end{array}$ & 759 & $2.085 \pm 0.092^{* * *}$ & $-0.147 \pm 0.064^{*}$ & $-0.350 \pm 0.038^{* * *}$ & $-0.685 \pm 0.044^{* * *}$ & $0.009 \pm 0.003^{* *}$ & $-0.020 \pm 0.005^{* * *}$ & $-0.141 \pm 0.038^{* * *}$ & $-0.053 \pm 0.064$ \\
\hline $\begin{array}{l}\text { Maximum } \\
\text { height }\end{array}$ & 758 & $3.931 \pm 0.068^{* * *}$ & $-0.032 \pm 0.045$ & $0.339 \pm 0.029^{* * *}$ & $0.676 \pm 0.030^{* * *}$ & $0.006 \pm 0.002^{*}$ & $-0.007 \pm 0.003^{*}$ & $0.281 \pm 0.029^{* * *}$ & $-0.177 \pm 0.045^{* *}$ \\
\hline
\end{tabular}

a Standard deviations (SD) of random factors for the mortality model are as follows: Sub-sample plot: (Sample plot:Site) SD 1.639; Sample plot:Site SD 0.002; Site SD 0.007. For the sprout number model: Sub-sample plot: (Sample plot:Site) SD 0.209; Sample plot:Site SD 0.001; Site SD 0.001. For the maximum height model: Sub-sample plot:Sample plot SD 0.144; Sample plot SD<0.001

${ }^{b}$ Difference between the control and the fungal (C. purpureum) treatment

${ }^{c}$ Difference between year 2018, and 2019 and 2020 in the control

${ }^{d}$ The effect of stump diameter $(\mathrm{mm})$ measured at height $20 \mathrm{~cm}$ from soil surface

e The effect of other saplings and stumps around an investigated sapling within $0.5 \mathrm{~m}$ radius

${ }^{f}$ Difference between stumps without and with old branches on a stump

${ }^{9}$ Difference between site 1 (Orivesi, older) and site 2 (Ruovesi, younger)

However, no difference was found between the fungal treatment and the control when the maximum height of stump sprouts was considered.

In earlier investigations of fully mechanized sprout control devices, the sprout control efficacy has been similar to what was observed in this study (ca. 35-40\% stump mortality). In experiments where the sprout control efficacy of a UW40 brushwood cutter attached to a mini harvester Tehojätkä (Usewood Ltd., Finland) was investigated, the stump mortality was ca. $34 \%$ (Laine et al. 2019, 2020a), whereas for another precommercial thinning device, MenSe RP6L cutter (Mense Ltd., Finland), stump mortality was $42 \%$ (Laine et al. 2019). However, in these studies, the final sprout control efficacy was investigated three years after the treatment, i.e., one year later than in the present study, and as stump mortality may still increase (Hamberg et al. 2014, Laine et al. 2020a), the comparable efficacy of Cutlink is probably higher than that reported here. However, in the earlier studies, more detailed analyses were not performed to identify the possible effects of stump height or the occurrence of older branches. The present study revealed that the sprout control efficacy can be higher than $40 \%$ if stump height is low after cutting and if a stump does not include older branches.
In the fungal treatment of the younger site (Ruovesi), the sprout control efficacy of Cutlink was very good in stumps without old branches (73\%). This corresponds to the efficacy that has been achieved in silver and downy birch and some other deciduous tree species when fungal inoculum has been spread precisely on freshly cut stump surfaces using a squirt bottle or a backpack sprayer (Scheepens and Hoogerbrugge 1989, Harper et al. 1999, Vartiamäki et al. 2009, Lygis et al. 2012, Hamberg and Hantula 2016, Hamberg et al. 2014, 2015, 2020). Furthermore, it should be noted that in the present study the basal suspension was diluted more (1:100) than in earlier Finnish studies, where the diluted inoculum medium (1:10) was spread on stump surfaces manually (Vartiamäki et al. 2009, Hamberg and Hantula 2016, Hamberg et al. 2014, $2015,2020)$. Therefore, the observed stump mortality $(73 \%)$ in the present study can be considered very promising.

The method of how the Cutlink cleaning head collects saplings, cuts them, and spreads inoculum medium directly onto freshly cut stumps, appears efficient. Although at the older site (Orivesi) there were also stumps that had no old branches, stump mortality was clearly lower than at the younger site (Ruovesi). Potential explanations for the result may be found both in site characteristics and the fact that the Cutlink operator was not an experienced user of the device. The older 

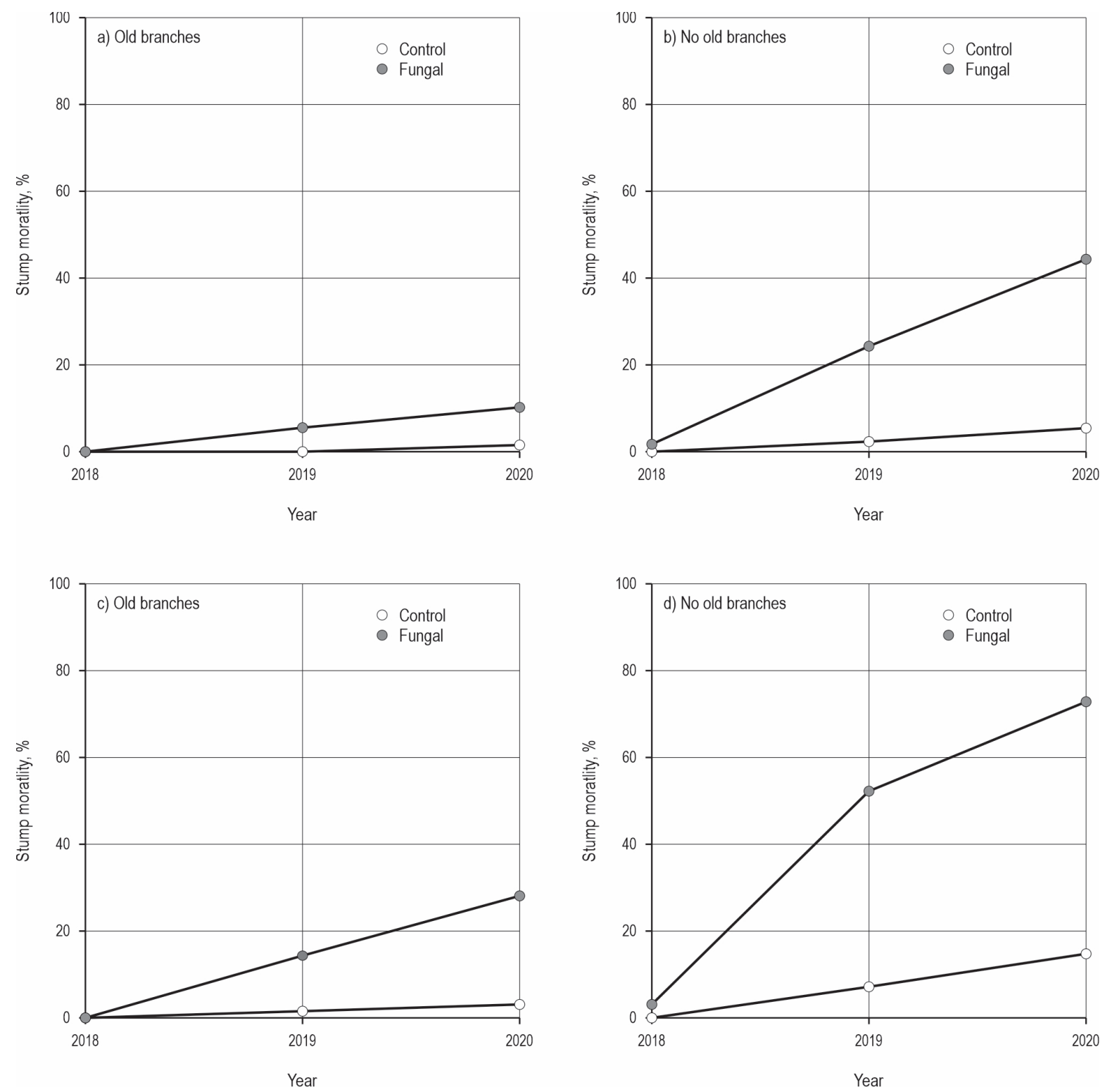

Fig. 3 Effects of the control (cutting only) and the fungal treatment (cutting and applying fungal inoculum including hyphae of Chondrostereum purpureum) on the stump mortality of silver and downy birches (Betula pendula and B. pubescens) (a-b) at site 1 (Orivesi: older, upper row), and (c-d) site 2 (Ruovesi: younger, lower row) when old branches - grown before cutting - occur or not on stumps after the treatments. Both control (cutting only) and the fungal treatment have been performed using the Cutlink cleaning head (with a spreading feature for the fungal treatment). Values in the figures have been calculated based on the estimated models. See Table 3

site was more difficult in terms of sprout control since saplings were taller, and it included large stones that had to be avoided. Combined with the inexperienced operator this may have yielded lower stump mortality percentages (due to higher stumps and consequently higher occurrence of old branches) than at the second site which was easier to operate in (no stones).

The occurrence of old branches on stumps seemed to be critical to sprout control efficacy. Stump mortal- ity was clearly higher in stumps without old branches. When a stump has living branches capable of photosynthesis it appears to tolerate the fungal infection better than stumps without old branches. Investigations in clonal tree species, such as in aspen (Populus tremula) and rowan (Sorbus aucuparia L.), have indicated that, although a stump has been treated with fungal inoculum, it can withstand C. purpureum better if conspecific saplings or trees possibly belonging to 

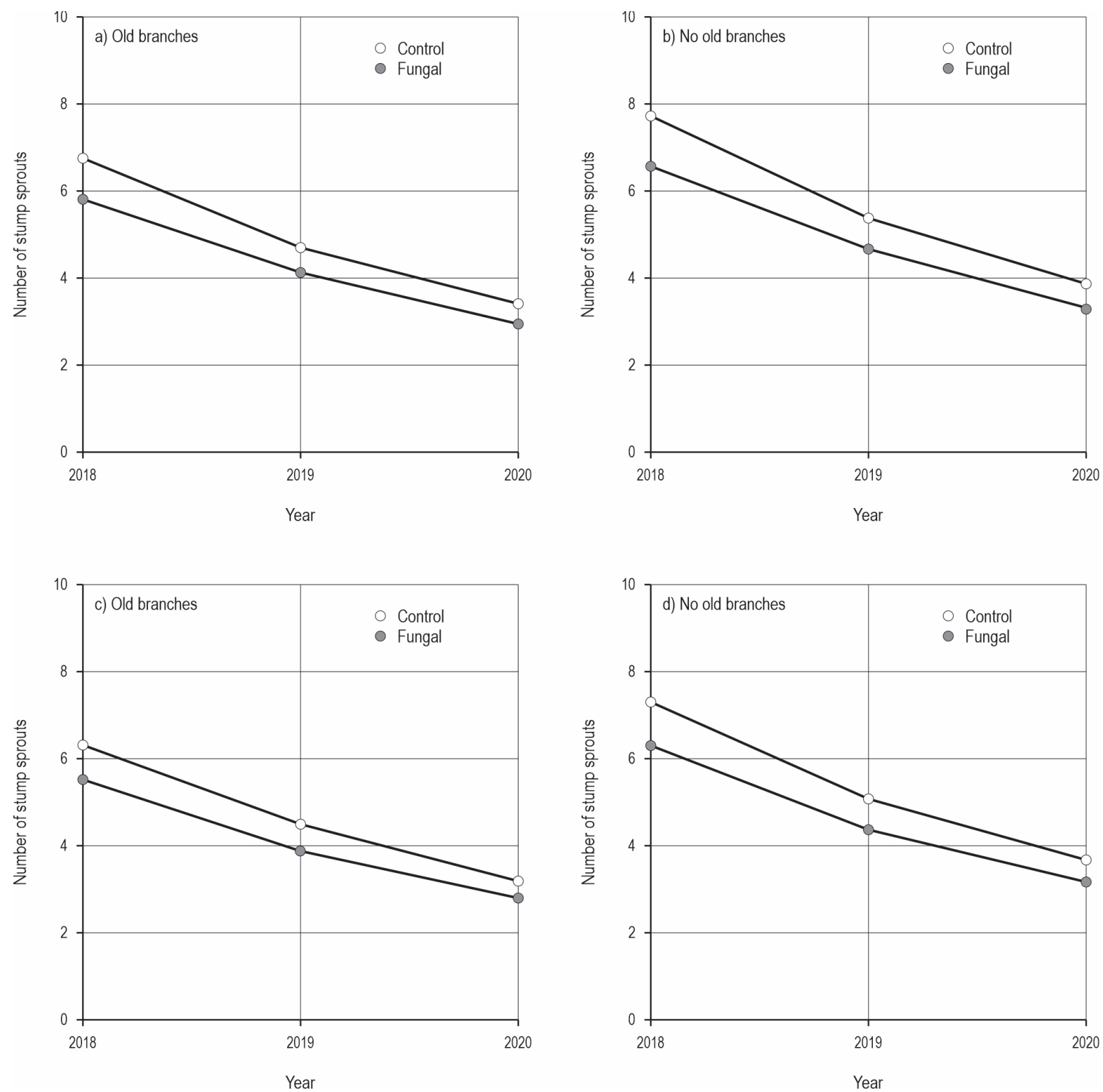

Fig. 4 Effects of the control (cutting only) and the fungal treatment (cutting and applying fungal inoculum including hyphae of Chondrostereum purpureum) on the number of stump sprouts of silver and downy birches (Betula pendula and B. pubescens) (a-b) at site 1 (Orivesi: older), and (c-d) site 2 (Ruovesi: younger) when old branches - grown before cutting - occur or not on stumps after the treatments. Both control (cutting only) and the fungal treatment have been performed using the Cutlink cleaning head (with a spreading feature in the fungal treatment). Values in the figures have been calculated based on the estimated models. See Table 3

the same clone exist nearby (Hamberg et al. 2014, Hamberg and Hantula 2016). In clonal species, underground parts of the clone can connect separate saplings (Suvanto and Latva-Karjanmaa 2005), and therefore living parts of the clone can support those suffering. Silver and downy birches do not have underground connections to other saplings, but most probably old branches on stumps have provided support during the fungal infection.
The number of new stump sprouts was also lower in stumps with old branches. Probably there is no need for new sprouts if old ones are capable of photosynthesis. The effect of old branches on the maximum height of stump sprouts was clear, since stumps with older branches had clearly higher sprouts, even as much as $30 \mathrm{~cm}$ higher than those without them. Yet, the number of new stump sprouts was lower in the fungal treatment than in the control 

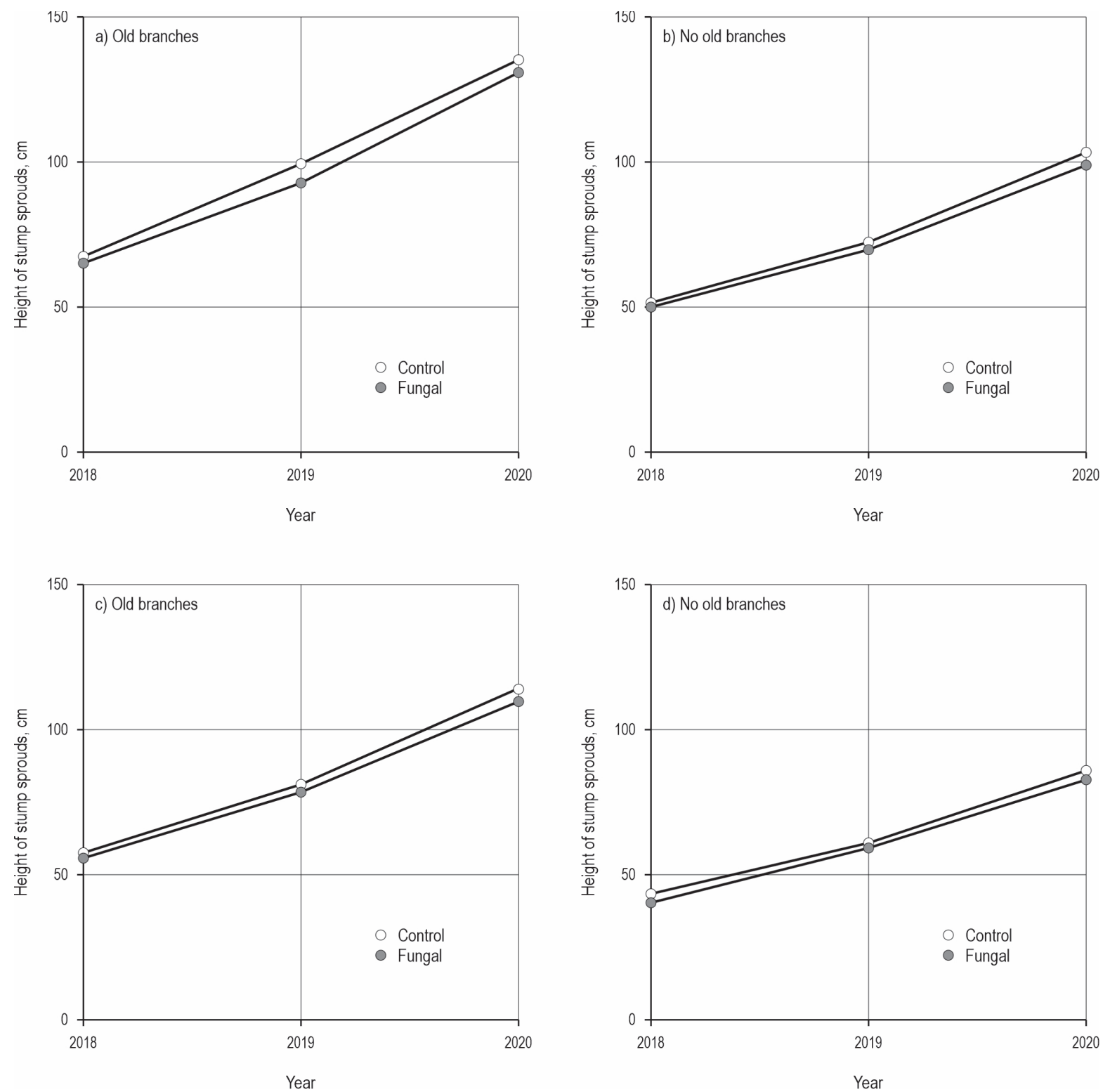

Fig. 5 Effects of the control (cutting only) and the fungal treatment (cutting and applying fungal inoculum including hyphae of Chondrostereum purpureum) on the maximum height of stump sprouts of silver and downy birches (Betula pendula and B. pubescens) (a-b) at site 1 (Orivesi: older), and (c-d) site 2 (Ruovesi: younger) when old branches - grown before cutting - occur or not on stumps after the treatments. Note that the highest new stump sprout or old branch has been measured as the highest stump sprout here depending on which one is the highest. Both control (cutting only) and the fungal treatment have been performed using the Cutlink cleaning head (with a spreading feature for the fungal treatment). Values in the figures have been calculated based on the estimated models. See Table 3

but no difference was found in terms of the maximum height of stump sprouts, similarly to observations in prior studies (e.g., Jobidon 1998, Vartiamäki et al. 2009).

Interestingly, the effect of old branches was evident when concerning the occurrence of fruiting bodies of $C$. purpureum. Fruiting bodies were more common in stumps without old branches, which in- dicates that the fungus has been able to invade these stumps better than those with old branches (Wall 1997). C. purpureum fruits only on dying and recently killed trees, and therefore fruiting bodies can be found at that time, but if a tree dies slowly fructification can occur over a longer time, and in trees that fully recover from C. purpureum infection, fructification does not necessarily occur at all. 
Table 4 Occurrence of fruiting bodies of decay fungus Chondrostereum purpureum (\%) on birch, Betula pendula and B. pubescens, stumps in the control and in the fungal (C. purpureum) treatment, one, two and three growing seasons after the treatments in 2018, 2019 and 2020 on stumps having old branches and on those without old branches

\begin{tabular}{|c|c|c|c|c|c|c|c|c|}
\hline \multirow{3}{*}{ Site } & \multirow{3}{*}{ Treatment } & \multirow{3}{*}{$n^{a}$} & \multirow{2}{*}{\multicolumn{2}{|c|}{$\begin{array}{c}\text { After the first growing season } 2018 \\
\text { Fruiting bodies, \% }\end{array}$}} & \multirow{2}{*}{\multicolumn{2}{|c|}{$\begin{array}{c}\text { After the second growing season } 2019 \\
\text { Fruiting bodies, \% }\end{array}$}} & \multirow{2}{*}{\multicolumn{2}{|c|}{$\begin{array}{c}\text { After the third growing season } 2020 \\
\text { Fruiting bodies, } \%\end{array}$}} \\
\hline & & & & & & & & \\
\hline & & & Branches & No branches & Branches & No branches & Branches & No branches \\
\hline \multirow{2}{*}{ Orivesi } & C. purpureum & 75 & 0 & 11 & 19 & 50 & 19 & 39 \\
\hline & Control & 74 & 0 & 0 & 0 & 0 & 0 & 0 \\
\hline \multirow{2}{*}{ Ruovesi } & C. purpureum & 75 & 0 & 0 & 8 & 59 & 19 & 33 \\
\hline & Control & 75 & 0 & 0 & 0 & 6 & 0 & 0 \\
\hline
\end{tabular}

${ }^{\text {a }}$ Per year

Stump mortality increased with increasing stump diameter. This result verifies the results of earlier studies (Hamberg and Hantula 2020, Hamberg et al. 2014, 2015, 2020, Laine et al. 2019, 2020a, b). In the fungal treatment, larger stump surface area can receive more fungal fragments, and therefore it is easier for the fungus to penetrate wood tissue, whereas in small diameter stumps, it is more difficult to apply fungal inoculum on stump surfaces and therefore a lower number of fungal fragments successfully adhere to the stump surface, yielding consequently lower and slower stump mortality. On the other hand, in larger living stumps, there were more and higher stump sprouts than in smaller stumps (see also Laine et al. 2019, 2020a, b, Hamberg et al. 2020). If a large stump stays alive, it has better resources to produce more and higher stump sprouts than a thinner stump (Hamberg and Hantula 2018).

The number of other saplings and stumps around an investigated sapling affected its probability to die, and if it stayed alive, its ability to produce stump sprouts. The probability of a stump to die increased with increasing number of other saplings and stumps around it (similarly as in Hamberg et al. 2014, Laine et al. 2019), and this seems to relate to a combined effect of the treatment (cutting and fungal infection) and competition. As coping with both factors requires resources, increasing competition in addition to fungal infection may be too much for saplings to stay alive. The same effect was also observed concerning the number of stump sprouts and their height: increasing competition for water, nutrients, solar radiation and growing space can reduce resources available for sprout growth (Jones and Harper 1987, Hamberg et al. 2011, 2015, Hamberg and Hantula 2018, Laine et al. 2019, 2020a, b).
Although this study showed that the Cutlink cleaning head with a spreading system is promising in biological sprout control, some features should be improved before it can be used in practical sprout control. The Cutlink operator should be able to cut shorter stumps that potentially do not have old branches capable of keeping stumps alive and also cut better small-diameter saplings. In Cutlink, the total consumption of fungal inoculum with 1:100 dilution was 580 litre per hectare, whereas with a UW40 brushwood cutter with 1:10 dilution it was 399.4 litre per hectare in a study by Laine et al. (2020b). Thus, the consumption of undiluted basal solution was lower with the Cutlink than the UW40, i.e., ca. 5.8 and 39.9 litre per hectare, respectively. Considering the promising stump mortality at the Ruovesi site in stumps without old branches, the 1:100 dilution may be enough for efficient sprout control if inoculum can be spread efficiently on freshly cut stump surfaces. Further development actions could also concentrate on exact spreading methods in order to achieve a cost-efficient sprout control method.

The proportion of saplings cut with the Cutlink cleaning head was just over $50 \%$ in this study. The performance of the device from this point of view must be improved before it will be ready for practical young stand management work. The same problem has also been detected in a study where the Cutlink cleaning head was compared with motor-manual brush saw work (Routa et al. 2020).

\section{Conclusions}

We conclude that the fully mechanized device, a Cutlink cleaning head with a spreading feature is promising in biological sprout control, but its efficacy 
should be improved. Especially, it should be able to cut a larger proportion of saplings in an area, stumps should be shorter without old branches and the spreading feature could be improved in order to decrease the consumption of fungal inoculum. These improvements could help in creating a cost efficient, fully mechanized device for forestry.

\section{Acknowledgments}

We thank Metsähallitus for providing sites for the study, Petteri Pieti for providing the Cutlink cleaning head and harvester for the study and for cutting saplings and applying fungal inoculum on freshly cut stumps. Pekka Seiskari, Verdera Ltd., provided fungal inoculum for the study, and Markku Rantala and Harri Lindeman helped in the field. Metsäteho Ltd. is acknowledged for the funding which enabled the addition of a spreading feature to the Cutlink cleaning head. Language was checked by Heikki Kiheri. The study was funded by the Natural Resources Institute Finland (project numbers 41007-00140900 for LH, 41007-00096400 for TS) and Metsäteho Ltd. (project 468 for MS).

\section{References}

Äijälä, O., Koistinen, A., Sved, J., Vanhatalo, K., Väisanen, P., (eds) 2019: Metsänhoidon suositukset. Forestry Development Centre Tapio: Helsinki, Finland; 252 p. [Forest management recommendations in Finland].

Bates, D., Maechler, M., Bolker, B., Walker S., 2015: Fitting linear mixed-effects models using lme4. J Stat Softw 67(1): 1-48. https://doi.org/10.18637/jss.v067.i01.

Becker, E., Shamoun, S.F., Hintz, W.E., 2005: Efficacy and environmental fate of Chondrostereum purpureum used as a biological control for red alder (Alnus rubra). Biol Control 33(3): 269-277. https://doi.org/10.1016/j.biocontrol.2005.02.013

Bellgard, S.E., Johnson, V.W., Than, D.J., Anand, N., Winks, C.J., Ezeta, G., Dodd, S.L., 2014: Use of the silverleaf fungus Chondrostereum purpureum for biological control of stump sprouting, riparian weedy tree species in New Zealand. Australas Plant Path 43(3): 321-326. https://doi.org/10.1007/ s13313-014-0273-z

Cajander, A.K., 1926: The theory of forest types. Acta For Fenn 29: 1-108.

de Jong, M.D., 2000: The BioChon story: deployment of Chondrostereum purpureum to suppress stump sprouting in hardwoods. Mycologist 14(2): 58-62. https://doi.org/10.1016/ S0269-915X(00)80005-1

Dumas, M.T., Wood, J.E., Mitchell, E.G., Boyonoski, N.W., 1997: Control of stump sprouting of Populus tremuloides and P. grandidentata by inoculation with Chondrostereum purpu- reum. Biol Control 10(1): 37-41. https://doi.org/10.1006/ bcon.1997.0507

Ethridge, D.E., Morin, L.A., 1963: Colonization by decay fungi of living and dead stems of balsam fir following artificial injury. Can J Bot 41(10): 1532-1534. https://doi. org/10.1139/b63-134

Gonzáles, J.M., 1996: A general purpose program for obtaining most probable number tables. J Microbiol Meth 26(3): 215-218. https://doi.org/10.1016/0167-7012(96)00818-4

Gosselin, L., Jobidon, R., Bernier, L., 1995: Assessment of genetic variation within Chondrostereum purpureum from Quebec by random amplified polymorphic DNA analysis. Mycol Res 100(2): 151-158. https://doi.org/10.1016/S09537562(96)80113-4

Hamberg, L., Hantula, J., 2016: The efficacy of six elite isolates of the fungus Chondrostereum purpureum against the sprouting of European aspen. J Environ Manage 171: 217224. http://dx.doi.org/10.1016/j.jenvman.2016.02.016

Hamberg, L., Hantula, J., 2018: Tree size as a determinant of recovery of birch (Betula pendula and B. pubescens) and grey alder (Alnus incana) trees after cutting and inoculation with Chondrostereum purpureum. Biol Control 126: 83-89. https:// dx.doi.org/10.1016/j.biocontrol.2018.07.015

Hamberg, L., Hantula, J., 2020: The biocontrol efficacy of Chondrostereum purpureum is not sensitive to prevailing environmental conditions in boreal forests. For Ecol Manage 456: 117646. https://doi.org/10.1016/j.foreco.2019.117646

Hamberg, L., Vartiamäki, H., Hantula, J., 2015: Breeding increases the efficacy of Chondrostereum purpureum in the sprout control of birch. PLoS ONE 10(2): e0117381. https:// doi.org/10.1371/journal.pone.0117381

Hamberg, L., Lemola, J., Hantula, J., 2017: The potential of the decay fungus Chondrostereum purpureum in the biocontrol of broadleaved tree species. Fungal Ecol 30: 67-75. https://doi.org/10.1016/j.funeco.2017.09.001

Hamberg, L., Malmivaara-Lämsä, M., Löfström, I., Hantula, J., 2014: Effects of a biocontrol agent Chondrostereum purpureum on sprouting of Sorbus aucuparia and Populus tremula after four growing seasons. BioControl 59(1): 125-137. https://dx.doi.org/10.1007/s10526-013-9550-y

Hamberg, L., Vartiamäki, H., Malmivaara-Lämsä, M., Löfström, I., Valkonen, S., Hantula, J., 2011: Short-term effects of mechanical and biological treatments on Sorbus aucuparia L. sprouting in mesic forests in Finland. Scand J For Res 26(6): 505-514. https://doi.org/10.1080/02827581.2011.59 2144

Hamberg, L., Saarinen, V.-M., Rantala, M., Hantula, J., Seiskari, P., Saksa, T., 2020: Rainstorm effects on the biocontrol efficacy of the decay fungus Chondrostereum purpureum against birch sprouting in boreal forests. Appl Microbiol Biotech 104(11): 5107-5117. https://doi.org/10.1007/s00253020-10574-3 
Harper, G.J., Comeau, P.G., Hintz, W., Wall, R.E., Prasad, R., Becker, E.M., 1999: Chondrostereum purpureum as a biological control agent in forest vegetation management. II. Efficacy on Sitka alder and aspen in western Canada. Can J For Res 29(7): 852-858. https://doi.org/10.1139/x99-121

Huuskonen, S., Haikarainen, S., Sauvula-Seppälä, T., Salminen, H., Lehtonen, M., Siipilehto, J., Ahtikoski, A., Korhonen, K.T., Hynynen, J., 2020: Benefits of juvenile stand management in Finland - impacts on wood production based on scenario analysis. Forestry 93(3): 458-470. https://doi. org/10.1093/forestry/cpz075

Jobidon, R., 1998: Comparative efficacy of biological and chemical control of the vegetative reproduction in Betula papyrifera and Prunus pensylvanica. Biol Control 11(1): 22-28. https://doi.org/10.1006/bcon.1997.0573

Jones, M., Harper, J.L., 1987: The influence of neighbours on the growth of trees I. The demography of buds in Betula pendula. Proc Royal Soc B Biol Sci 232(1266): 1-18. https://doi. org/10.1098/rspb.1987.005

Laine, T., Hamberg, L., Saarinen, V.-M., Saksa, T., 2019: The efficacy of Chondrostereum purpureum against sprouting of deciduous species after mechanized pre-commercial thinning. Silva Fenn 53(3): article id 10195. https://doi. org/10.14214/sf.10195

Laine, T., Hamberg, L., Saarinen, V.-M., Saksa, T., 2020a: The efficacy of Chondrostereum purpureum in the sprout control of birch during mechanized pre-commercial thinning. BioControl 65(1): 13-24. https://doi.org/10.1007/s10526-01909971-z

Laine, T., Saarinen, V.-M., Hantula, J., Saksa T., Hamberg, L., 2020b: Efficacy of different clearing saw methods in biological sprout control in birch (Betula pendula [Roth] and B. pubescens [Ehrh.]) compared to manual and mechanized application. For Ecol Manage 475: 118429. https://doi. org/10.1016/j.foreco.2020.118429

Lygis, V., Bakys, R., Burokienė, D., Vasiliauskaitė, I., 2012: Chondrostereum purpureum based control of stump sprouting of seven hardwood species in Lithuania. Baltic For 18(1): 41-55.

Mazerolle, M.J., 2019: AICcmodavg: Model selection and multimodel inference based on (Q)AIC(c). R package version 2.2-2. https://cran.r-project.org/package=AICcmodavg

[PEFC] The Programme for the Endorsement of Forest Certification, 2017: Criteria for PEFC Forest Certification. PEFC FI 1002:2014. 49 p.

Pinheiro, J., Bates, D., DebRoy, S., Sarkar, D., R Core Team, 2019: nlme: Linear and nonlinear mixed effects models. R package version 3.1-142.

Pitt, D.G., Dumas, M.T., Wall, R.E., Thompson, D.G., Lanteigne, L., Hintz, W., Sampson, G., Wagner, R.G., 1999: Chondrostereum purpureum as a biological control agent in forest vegetation management. I. Efficacy on speckled alder, red maple, and aspen in eastern Canada. Can J For Res 29(7): 841-851. https://doi.org/10.1139/x99-122
R Core Team, 2019: R: A language and environment for statistical computing. R Foundation for Statistical Computing, Vienna, Austria.

Ramsfield, T.D., Becker, E.M., Rathlef, S.M., Tang, Y., Vrain, T.C., Shamoun, S.F., Hintz, W.E., 1996: Geographic variation of Chondrostereum purpureum detected by polymorphisms in the ribosomal DNA. Can J Bot 74(12): 1910-1929. https://doi. org/10.1139/b96-229

Routa, J., Nuutinen, Y., Asikainen, A., 2020: Productivity in mechanizing early tending in spruce seedling stands. Croat J For Eng 41(1): 1-11. https://doi.org/10.5552/crojfe.2020.619

Roy, V., Dubeau, D., Auger, I., 2010: Biological control of intolerant hardwood competition: Silvicultural efficacy of Chondrostereum purpureum and worker productivity in conifer plantations. For Ecol Manage 259(8): 1571-1579. https:// doi.org/10.1016/j.foreco.2010.01.033

Scheepens, P.C., Hoogerbrugge, A., 1989: Control of Prunus serotina in forests with the endemic fungus Chondrostereum purpureum. Proc VII Int Symp Biol Contr Weeds, Rome, Italy, 6-11 March 1988; In: Delfosse, E.S., Ed. 1st Sper. Patol. Veg. (MAF), 545-551 p.

Spiers, A.G., Hopcroft, D.H., 1988: Factors affecting Chondrostreum purpureum infection of Salix. Eur J For Path 18(5): 257-278. https://doi.org/10.1111/j.1439-0329.1988.tb00214.x

Suvanto, L.I., Latva-Karjanmaa, T.B., 2005: Clone identification and clonal structure of the European aspen (Populus tremula). Mol Ecol 14(9): 2851-2860. https://doi.org/10.1111/ j.1365-294X.2005.02634.x

Thiffault, N., Roy, V., 2011: Living without herbicides in Québec (Canada): historical context, current strategy, research and challenges in forest vegetation management. Eur J For Res 130(1): 117-133. https://doi.org/10.1007/s10342-0100373-4

Vartiamäki, H., Maijala, P., Uotila, A., Hantula, J., 2008a: Characterization of growth and enzyme production of Chondrostereum purpureum isolates and correlation of these characteristics with their capability to prevent sprouting of birch in field. Biol Control 47(1): 46-54. https://doi.org/10.1016/j. biocontrol.2008.06.005

Vartiamäki, H., Uotila, A., Vasaitis, R., Hantula, J., 2008b: Genetic diversity in Nordic and Baltic populations of Chondrostereum purpureum - a potential herbicide biocontrol agent. For Path 38(6): 381-393. https://doi.org/10.1111/j.14390329.2008.00551.x

Vartiamäki, H., Hantula, J., Uotila, A., 2009: Effect of application time on the efficacy of Chondrostereum purpureum treatment against the sprouting of birch in Finland. Can J For Res 39(4): 731-739. https://doi.org/10.1139/X09-009

Wagner, R.G., Little, K.M., Richardson, B., Mcnabb, K., 2006: The role of vegetation management for enhancing productivity of the world's forests. Forestry 79(1): 57-79. https://doi. org/10.1093/forestry/cpi057 
Wall, R.E., 1997: Fructification of Chondrostereum purpureum on hardwoods inoculated for biological control. Can J Plant Path 19(2): 181-184. https://doi.org/10.1080/ 07060669709500550
Willoughby, I., Balandier, P., Bentsen, N.S., McCarthy, N., Claridge, J., 2009: Forest vegetation management in Europe: current practices and future requirements. European cooperation in science and technology (COST) Office, $156 \mathrm{p}$.

(C) 2022 by the authors. Submitted for possible open access publication under the terms and conditions of the Creative Commons Attribution (CC BY) license (http://creativecommons.org/licenses/by/4.0/).

Authors' addresses:

Leena Hamberg, PhD *

e-mail: leena.hamberg@luke.fi

Natural Resources Institute Finland (Luke)

Latokartanonkaari 9

FI-00790 Helsinki

FINLAND

Markus Strandström

e-mail: markus.strandstrom@metsateho.fi

Metsäteho Ltd.

Vernissakatu 1

FI-01300 Vantaa

FINLAND

Timo Saksa, PhD

e-mail: timo.saksa@luke.fi

Natural Resources Institute Finland (Luke)

Juntintie 154

FI-77600 Suonenjoki

FINLAND

* Corresponding author 